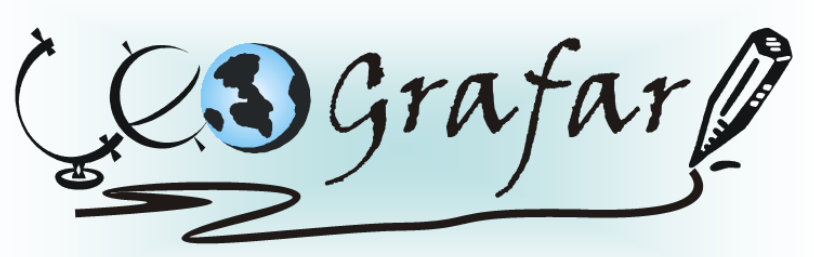

Revista Eletrônica do Programa de Pós-Graduação em Geografia - UFPR

\title{
MODERNIZAÇÃO DA AGRICULTURA, EXPANSÃO DA SOJA NO BRASIL E AS TRANSFORMAÇÕES SOCIOESPACIAIS NO PARANÁ
}

\author{
MARGARIDA CASSIA CAMPOS ${ }^{1}$
}

\begin{abstract}
RESUMO
O presente artigo discute os principais fatores que foram preponderantes na expansão da soja em várias regiões brasileiras. Além de destacar que nas últimas décadas a agropecuária passou por profundas transformações, como a centralização de capitais (via articulação do capital monopolista), ocupação de novas áreas (em especial o Centro-Oeste), desagregação da produção de autoconsumo, transformação de parte da pequena produção em produção especializada e com alta produtividade integrada ao mercado e de uma parte do latifúndio em empresas capitalistas, expansão na produção de alimentos para o mercado interno e externo, esse último se realizou a partir de uma inserção competitiva do Brasil no mercado mundial de alimentos por meio do crescimento e da diversificação dos produtos agrícolas, êxodo rural, utilização de pouca mão-de-obra para o trabalho agrícola, intensa mecanização e utilização de insumos, suporte técnico e cientifico ofertado por empresas privadas e pelo Estado. Sendo assim, a cultura eleita como "carro chefe" das mudanças na base técnica da produção, desencadeado a partir de meados da década de 1960, foi sem dúvida a soja. Sua expansão teve suporte estatal nunca visto no Brasil, através de oferta de crédito abundante para a compra de máquinas e insumos. Até mesmo quando a política não era dirigida à soja, esta obteve benefícios. Todas essas mudanças provocaram transformações socioespaciais nos mais diversos lugares por onde a soja se expandiu. No referido artigo o estado do Paraná, segundo maior produtor brasileiro, recebeu atenção especial, com uma analise de como ocorreu tais mudanças tanto nas técnicas de produção, na estrutura social, econômica e consequentemente na reorganização espacial.
\end{abstract}

Palavras-chaves: modernização, agricultura, soja, Paraná, transformações socioespaciais

\footnotetext{
${ }^{1}$ Doutora em Geografia pela Universidade Federal de Santa Catarina
} 


\title{
MODERNIZATION OF AGRICULTURE, EXPANSION OF SOYBEAN IN BRAZIL AND THE TRANSFORMATION SOCIOSPATIAL IN PARANA
}

\begin{abstract}
The present article discussed the main factors that were preponderant in the expansion of the soybean in several Brazilian areas. Besides highlighting that in the last decades the farming went by deep transformations, as the centralization of capitals (through the capital monopolist's articulation), occupation of new areas (especially the Center-west), disaggregation of the self-consumption production, transformation of part of the small production in specialized production and with high productivity integrated into the market and of a part of the latifundium in capitalist companies, expansion in the production of foods to the internal and external market, that last one took place starting from a competitive insert of Brazil in the world market of foods through the growth and of the diversification of the agricultural products, rural exodus, use of little labor for the work agricultural, intense mechanization and use of inputs, technical support and I inform presented by deprived companies and for the State. Being like this, the elect culture as car boss of the changes in the technical base of the production, unchained starting from middles of the decade of 1960, was without a doubt the soy. His expansion had state support seen never in Brazil, through offer of abundant credit for the purchase of machines and inputs. Even when the politics was not driven to the soybean, this obtained benefits. All those changes provoked transformations sociospatial in the most several places through where the soy expanded. In referred him article the state of Paraná, second Brazilian producing adult, received special attention, with one analyzes of as happened such changes so much in the production techniques, in the structure social, economical and consequently in the space reorganization.
\end{abstract}

Keywords: modernization, agriculture, soybean, Parana, transformation sociospatial

\section{INTRODUÇÃO}

O estudo da expansão da soja oferece uma visão de totalidade das metamorfoses impressas no espaço geográfico brasileiro a partir da modernização e dinamização da agricultura pós 1964. Assim, os diversos lugares e regiões apresentaram transformações diferenciadas e múltiplas em seus fluxos e fixos, com objetivo de racionalizar a expansão da referida oleaginosa. É um processo que, ao mesmo tempo que ocorre em uma escala local, acarreta um esquema complexo e denso de transformações socioespaciais regionais e nacionais, por isso recoloca o estudo do lugar em uma posição central. 
O lugar é o palco dos conflitos, da dialética e das contradições. Sendo assim, a expansão da soja no território nacional torna-se um tema riquíssimo para o pesquisador em geografia estudar as mudanças da tecnificação da agricultura no período técnico, científico e informacional e suas consequências nas novas configurações espaciais, bem como os conflitos entre os produtores, as multinacionais e o governo e os interesses que permeiam todos esses atores.

Atualmente, o Brasil é o segundo maior produtor de soja mundial e, segundo previsões da USDA, será o maior produtor em 2015. A historiografia do plantio de soja no país remonta o final do século XIX, cujos levantamentos indicam que até 50 anos atrás o Brasil produzia 125 mil toneladas de soja, ou seja, um número irrisório perto dos mais de 68 milhões de toneladas na safra 2009/10. Portanto, torna-se necessário estudar quais os fatores que levaram a esse crescimento espetacular.

Observa-se que houve vários testes de plantio de soja em algumas regiões do Brasil ${ }^{2}$ no final do século XIX. Nesse ínterim, não ocorreu nenhuma alteração do material genético (sementes) que chegaram dos Estados Unidos para condições edafoclimáticas brasileiras ${ }^{3}$. E por que isso não ocorreu? Cabe lembrar que o Brasil não possuía no início do século $X X$ institutos de pesquisas capazes de tal ato. $O$ Brasil ainda era um país agrário e exportador, carente de um setor industrial que pudesse dar suporte ao desenvolvimento de ciência e tecnologia agrícola em solo pátrio. Assim, as sementes disponíveis eram de países de clima temperado. Por essa razão, os estados que se destacavam no plantio de soja, até meados da década de 1970, eram o Rio Grande do Sul, Paraná e Santa Catarina.

Seguindo uma ordem cronológica do início da produção de soja nos estados brasileiros de maior importância na produção comercial da referida oleaginosa, até os dias atuais analisa-se as peculiaridades do plantio e da expansão da soja em algumas regiões e seus respectivos estados. $O$ objetivo desse relato é averiguar as

2 No Brasil, a soja foi introduzida em 1882, na Bahia pelo pesquisador Gustavo Dutra, que trouxe dos Estados Unidos algumas sementes. Em 1892 o Instituto Agronômico de Campinas/ SP, realizou testes de adaptação da soja em território brasileiro. A cultura encontrou clima similar no Rio Grande do Sul, tendo iniciado seu cultivo a partir de 1914. Em 1908, foram realizados plantios de soja por imigrantes japoneses nos Estados de São Paulo, com a finalidade de utilizar o grão para sua alimentação (BONATO e BONATO, 1987, p. 8 e 9).Nas estatísticas mundiais, o Brasil começou a aparecer como produtor de soja em 1949, com a produção de 25.000 toneladas. (MIYASAKA e MEDINA, 1981). Em 1940, a soja passa a ter importância econômica no Rio Grande do Sul ; nas duas décadas posteriores, a soja avança para os outros dois do sul do Brasil, em 1969, três Estados são responsáveis por produzir $98 \%$ de toda a produção brasileira.

${ }^{3} \mathrm{Na}$ Bahia (primeiro Estado onde as sementes foram testadas), a soja não teve êxito, pois as condições climáticas impediram seu desenvolvimento. 
condições em que a soja se expandiu nas mais diversas regiões do país, observando as diferentes mudanças socioespaciais ocorridas em lugares distintos.

As mudanças tecnológicas, juntamente com as demais políticas, criaram transformações socioespaciais no Paraná. Os eventos desse processo implantaram um ritmo acelerado em que os fixos e fluxos mudaram sua função e forma com uma velocidade nunca vista antes, provocando acentuada desigualdade, tanto na cidade como no campo. Por outro lado, houve uma territorialização do capital e oligopolização do espaço rural. Essa discussão também recebeu atenção especial no presente artigo.

O objetivo geral do artigo foi analisar quais os principais fatores de expansão da soja em algumas regiões do país, bem como destacar algumas mudanças ocorridas no espaço agrário brasileiro, após o processo de modernização da agricultura, e as transformações socioespaciais que ocorreram no estado do Paraná, a partir da expansão da soja. Para alcançar tal objetivo, o percurso metodológico passou por leituras de várias obras, com a finalidade de entender alguns temas, conceitos e ideias utilizados durante a pesquisa.

Um segundo aspecto metodológico foi o levantamento junto ao Ministério da Agricultura, Instituto Brasileiro de Geografia e Estatística, United States Department of Agriculture de dados da produção de soja no mundo e no Brasil, para responder a seguinte pergunta: em que momento histórico, os registros de produção de soja sofreram um efetivo aumento?

E, finalmente, compará-los e analisá-los com os temas, ideias e conceitos obtidos por meio da leitura das obras.

\section{FATORES DE EXPANSÃO DA SOJA NAS REGIÕES BRASILEIRAS}

Até a década de 1980, a cultura da soja esteve presente essencialmente nos três estados do sul do Brasil (Rio Grande do Sul, Santa Catarina e Paraná), sendo responsáveis por $98 \%$ da produção nacional.

Dentre os fatores responsáveis pela expansão da soja nesses estados, Dall'Agnol (2008, p.8 e seguintes) destaca: 
$\checkmark$ Semelhança do ecossistema do Sul do Brasil com aquele predominante no sul do Estados Unidos ${ }^{4}$, favorecendo o sucesso na transferência e adoção de cultivares e outras tecnologias de produção;

$\checkmark$ Estabelecimento da "Operação Tatu" (calagem e fertilização dos solos ácidos e inférteis) no Rio Grande do Sul, em meados da década de 1960, onde concentrava-se quase que a totalidade da produção de soja;

$\checkmark$ Incentivos fiscais disponibilizados aos agricultores de trigo, que utiliza no verão as mesmas áreas, mão de obra e máquinas agrícolas (nos anos de 1950, 1960 e 1970);

$\checkmark$ Mercado internacional em alta, principalmente em meados de 1970, em decorrência da frustração da colheita de grão na ex-União Soviética e China e da pesca de anchova no Peru, cujo farelo era completamente utilizado como componente proteico na fabricação de rações para animais domésticos, logo os fabricantes da ração passaram a utilizar a soja;

$\checkmark$ Substituição da gordura animal por óleo vegetal, em especial o oriundo da soja;

$\checkmark$ Criação de agroindústria para processar a soja estabelecimento de um importante parque industrial de desenvolvimento e produção de máquinas e implementos, assim como de produção de insumos nos anos de 1970 e 1980;

$\checkmark$ Melhoria no sistema viário para escoamento da produção em especial os portos e comunicações, facilitando e agilizando as exportações;

$\checkmark$ Aparecimento de um sistema de cooperativa (dinâmica e eficiente) que apoiou a produção, industrialização e comercialização da soja;

$\checkmark$ Facilidade de mecanização total da cultura;

$\checkmark \mathrm{E}$, finalmente, a instalação de vários órgãos de pesquisa públicos, em esfera estadual e federal, inclusive a EMBRAPA/Soja unidade Londrina, apoiados financeiramente pela indústria privada (Swilt, Anderson Clayton e Samrig etc). Segundo Bonato e Bonato (1987, p. 15 e seguintes), no Rio Grande do Sul existem registros sobre vendas realizadas por produtores já em 1935, bem como a primeira exportação de $6.420 \mathrm{Kg}$ de soja gaúcha em 1937. No início, a soja foi cultivada na região das missões, tendo como centro o município de Santa Rosa (produção de forragem e de grãos para arraçoamento de suínos). Nessa região, a

\footnotetext{
${ }^{4}$ De onde vieram as primeiras cultivares de soja para o Brasil.
} 
cultura foi utilizada em um processo de rotatividade com o trigo, normalmente semeada a partir de fins de novembro e durante o mês de dezembro. Sendo assim, ela se beneficiou da estrutura já encontrada para o cultivo do trigo. A partir de 1970, os agricultores passaram a ter problemas na produção do trigo e a soja já demonstrava bons retornos financeiros, ganhando espaço e tornando-se mais importante, em especial porque os preços da soja iniciaram uma escala crescente no mercado mundial no início da década de 1970. Algumas iniciativas de pesquisa e à incorporação de insumos, máquinas agrícolas, semeadeira-abubadeira e colheitadeiras e a melhoria das cultivares foram os fatores que lograram êxito a produção de soja nesse Estado, a partir de meados da década de 1950. Na safra de 1978/79, colheu-se mais de 4 milhões de hectares. Em 1985, o Estado ainda era responsável por 31.85\% da produção brasileira, na safra 2008/09 o Rio Grande do Sul contribuiu com cerca de $15 \%$ da colheita total de soja no território brasileiro.

Em Santa Catarina, ela também, a princípio, foi utilizada para alimentação de suínos. Bonato e Bonato (1987, p.16) comentam que a introdução da soja, no referido Estado, foi feita por agricultores oriundos do Rio Grande do Sul, sediados no oeste do Rio do Peixe, no início dos anos de 1930, antes dos agricultores se deslocarem para o Paraná. A produção de soja nesse estado apareceu nas estatísticas do IBGE na safra de 1951/52, com a área de 40 hectares e produção de 31 toneladas. Já, em 1985, apresenta 420.130 hectares de área plantada e 563.882 toneladas. No entanto, a soja não teve mesmo êxito de produção que no Rio Grande do Sul e no Paraná, por alguns motivos: características topográficas de parte do Estado, não sendo apropriadas para uma cultura que exige mecanização, a predominância de pequenas propriedades e porque os catarinenses preferiam plantar o milho com o objetivo de usá-lo para alimentação de suínos do que a soja; estes são fatores determinantes da baixa produção dessa oleaginosa nesse Estado.

No Paraná, os primeiros registros históricos da soja no estado são de 1936, quando os agricultores gaúchos e catarinenses começaram a se fixar nas regiões oeste e sudeste, onde a atividade principal era a criação de suínos (BONATO e BONATO, 1987, p. 20). Mas, como destaca MIYASAKA e MEDINA (1981, p. 22 e seguintes), as estatísticas indicam que até meados da década de 1960, a colheita de grãos nunca superou o volume de 60 toneladas. Até o início da década de 1970, o 
café, o milho e o feijão eram os produtos hegemônicos nesse Estado; o café no norte e nordeste e os outros produtos nas outras regiões.

No Centro-oeste, a soja ganha espaço após os anos de 1980, por meio da expansão da fronteira agrícola realizada principalmente por gaúchos, catarinenses e paranaenses, com a utilização de técnicas modernas na produção. Bernades (1996, p.328) destaca que entre os anos de 1980 e 1994 o volume de produção de soja cresceu 570,86\%, alcançando 10.128.984 toneladas em 1994, o que representa $40,66 \%$ da produção nacional.

Alguns fatores, segundo D'Agnoll (2008, p. 12 e seguintes), contribuíram para incorporação deste novo espaço pela cultura da soja, que hoje é o principal centro de produção:

$\checkmark$ Construção da rodovia Belém- Brasília e da capital Brasília, gerando melhorias nas condições de infraestrutura no centro-oeste, principalmente nas vias de acesso, comunicação e urbanização;

$\checkmark$ Incentivos fiscais para a abertura de novas áreas para a produção agrícola, no caso a expansão da soja no cerrado, está relacionada com os incentivos do Prodecer (Programa Nipo-Brasileiro de Cooperação para o Desenvolvimento do Cerrado);

$\checkmark$ Estabelecimento de agroindústrias produtoras e processadoras de grãos e de carne na região centro-oeste;

$\checkmark$ Baixo valor da terra, se comparados aos preços então praticados na região sul durante a década de 1960, 1970 e 1980;

$\checkmark$ Topografia muito favorável à mecanização, o que propicia a economia de mão de obra;

$\checkmark$ Boas condições pedológicas com a descoberta da técnica de calagem, que consiste na adição de calcário para reduzir a acidez do solo do cerrado, tornando-o produtivo;

$\checkmark$ Bom nível econômico e tecnológico dos produtores que ocuparam a região, oriundos do Sul onde cultivaram soja com sucesso;

$\checkmark$ Regime pluviométrico altamente favorável ao cultivo de verão;

$\checkmark$ O desenvolvimento de um bem sucedido conjunto de tecnologias para produção de soja nas áreas tropicais, transformando o Ecossistema do Cerrado, com mais de 200 milhões de hectares improdutivos em áreas com 
potencial para o cultivo da soja e de outros grãos. A EMBRAPA foi autor principal desse processo.

Tanto nos estados das regiões centro-oeste como no centro-sul, a expansão da soja se deu após os incentivos governamentais, quando ocorreram: a correção de solos antes impróprios para o plantio; a instalação de agroindústrias; a melhoria em logística territorial; a aplicação de técnicas modernas de produção juntamente com a criação da EMBRAPA/CNPSo e de outros institutos estaduais de pesquisas direcionados a melhoria das cultivares para o plantio no Brasil. Esses fatores provocaram um rápido incremento na produção de soja (ver tabela 1 e 2). Diante de tais afirmativas pode-se constatar que alguns desses fatores foram importantes também para a expansão da soja nas regiões norte e nordeste do Brasil

Após a última década do século XX, a soja passa a ser cultivada em alguns estados da região Norte e Nordeste, a partir da inserção destes novos espaços no plantio D'Agnoll (2008, p. 16) argumenta:

$\checkmark$ A expansão da soja no estado do Tocantins, Bahia (porção oeste da Bahia, destaque para a cidade de Barreiras), Maranhão (região do sul do estado, destaque para a cidade de Balsas) e Piauí (porção sul do estado), realiza-se através da incorporação de novas regiões do cerrado, reproduzindo a trajetória verificada pela oleaginosa na região centro-oeste ao que refere-se aos padrões técnicos de produção;

$\checkmark \quad \mathrm{Na}$ porção sul de Rondônia e Amazonas, a soja ganha espaço em áreas antes cobertas pela floresta Amazônica.

Na tabela 1 e 2, nota-se que em 10 anos (76/77 a 86/87) houve um expressivo crescimento na produção de soja ${ }^{5}$ no centro-oeste, na década seguinte a produção dobrou e quase triplicou de 1996/97 a 2006/07. Na região sul, de 1976/77 a 19996/97, a produção ficou praticamente estável, porém, na década seguinte, em função dos altos preços da soja no mercado mundial, no início do ano 2000, o sul também registrou um efetivo crescimento. Na região norte, em meados dos anos 1990, a produção era irrisória; na década seguinte, já passava de um milhão de toneladas, reflexo da incorporação de porções da floresta Amazônica no sul de Rondônia e Amazonas e dos ótimos preços da soja no mercado mundial. Com a

\footnotetext{
${ }^{5}$ Ao observar a tabela 3 e 4 e o mapa 1 é possível constatar que até meados da década de 1970 , $86,9 \%$ da área dedicada ao cultivo da soja era restrita a regiões de clima temperados e subtropicais em latitudes próximas ou superiores a $24^{\circ}$.
} 
incidência da BSE (doença da vaca louca) na Europa, houve uma demanda adicional da União Europeia, após o ano 2000, assim a soja transformou-se mais uma vez na alternativa natural, em substituição à farinha de carne, farinha de osso e de peixe proibidas para a alimentação animal. Este segmento exportou US\$4,1 bilhões em 2000, respondendo por um quarto do valor total das exportações do setor, significando que de cada US\$ 4,00 exportados em produtos agropecuários, US\$1,00 é do complexo soja.

TABELA 1 - ÁREA PLANTADA DE SOJA POR REGIÕES E ESTADOS DE 1976 A 2007 (MIL HECTARES)

\begin{tabular}{l|lllll}
\hline & $\mathbf{1 9 7 6 / 7 7}$ & $\mathbf{1 9 8 6 / 8 7}$ & $\mathbf{1 9 9 6 / 9 7}$ & $\mathbf{2 0 0 6 / 0 7}$ & $\begin{array}{l}\text { \%76/77- } \\
\mathbf{0 6 / 0 7}\end{array}$ \\
\hline Centro-Oeste & $\mathbf{3 7 8 , 0}$ & $\mathbf{2 . 8 6 7 , 8}$ & $\mathbf{3 . 9 8 3 , 8}$ & $\mathbf{9 . 1 0 5 , \mathbf { 1 }}$ & $\mathbf{2 . 3 0 8 , 7 5}$ \\
MT & 310 & 1.100 & $2.905,7$ & $5.124,8$ & $1.553,16$ \\
MS & - & 1.184 & 862,3 & $1.737,1$ & $46,71^{*}$ \\
GO & 68 & 540 & 991,2 & $2.191,4$ & $3.122,6$ \\
DF & - & 43,8 & 34,6 & 51,8 & $18,26^{*}$ \\
Sul & $\mathbf{6 . 0 4 1}$ & $\mathbf{5 . 2 9 6}$ & $\mathbf{5 . 6 8 0 , 8}$ & $\mathbf{8 . 2 4 7 , 4}$ & $\mathbf{1 2 6 , 5 2}$ \\
PR & 2.200 & 1.776 & $2.496,4$ & $3.978,5$ & 80,84 \\
SC & 351 & 360 & 240,2 & 376,9 & 7,37 \\
RS & 3.490 & 3.180 & $2.944,2$ & 3.892 & 11,51 \\
Nordeste & - & $\mathbf{1 8 0 , 6}$ & $\mathbf{5 9 3 , 9}$ & $\mathbf{1 . 4 5 4 , 9}$ & $\mathbf{7 0 5 , 5 9 ^ { * }}$ \\
MA & - & 8,5 & 120 & 384,4 & $4.422^{*}$ \\
PI & - & - & 17,9 & 219,7 & $1.127^{*}$ \\
PE & - & - & - & - & - \\
SE & - & - & - & - & - \\
BA & - & 170 & 456 & 850,8 & 400,47 \\
Sudeste & $\mathbf{5 3 0}$ & $\mathbf{8 7 6 , 7}$ & $\mathbf{1 . 0 9 7 , 6}$ & $\mathbf{1 . 4 6 8 , 8}$ & $\mathbf{1 7 7 , 1 3}$ \\
MG & 85 & 415 & 522,7 & 930,4 & 994,58 \\
ES & - & - & - & - & - \\
RJ & - & - & - & - & - \\
SP & 445 & 461,7 & 574,9 & 538,4 & 20,98 \\
Norte & - & $\mathbf{0 , 6}$ & $\mathbf{2 5 , 2}$ & $\mathbf{4 1 0 , 6}$ & $\mathbf{6 8 . 3 3 3 , 3 3 ^ { * }}$ \\
RR & - & 0,6 & - & 5,5 & $816,66^{*}$ \\
RO & - & - & 3,3 & 90,4 & $2.639,39^{* *}$ \\
AC & - & - & - & - & - \\
AM & - & - & - & - & - \\
AP & - & - & - & - & - \\
PA & - & - & 21,9 & 267,7 & $1.122,37^{* *}$ \\
TO & - & - & $\mathbf{1 1 . 3 8 1 , 3}$ & $\mathbf{2 0 . 6 8 6 , 8}$ & $\mathbf{2 9 7 , 6 9 \%}$ \\
Brasil & $\mathbf{6 . 9 4 9}$ & $\mathbf{9 . 2 2 1 , 7}$ & & &
\end{tabular}

* relativo aos anos de 1986/87 a 2006/07

** relativo aos anos de 1996/97 a 2006/07

FONTE: MAPA (2008) 
TABELA 2 - PRODUÇÃO DE SOJA POR REGIÕES E ESTADOS DE 1976 A 2007 (MIL TONELADAS)

\begin{tabular}{l|lllll}
\hline & $\mathbf{1 9 7 6 / 7 7}$ & $\mathbf{1 9 8 6 / 8 7}$ & $\mathbf{1 9 9 6 / 9 7}$ & $\mathbf{2 0 0 6 / 0 7}$ & $\begin{array}{l}\text { \%76/77- } \\
\mathbf{0 6} / \mathbf{0 7}\end{array}$ \\
\hline Centro-Oeste & $\mathbf{5 4 0 , 0}$ & $\mathbf{5 . 8 1 1 , 8}$ & $\mathbf{1 0 . 4 3 8 , 1}$ & $\mathbf{2 6 . 4 9 4 , 8}$ & $\mathbf{4 . 9 0 6 , 4 4}$ \\
MT & 450 & 2.387 & $5.721,3$ & 15.359 & $3.413,11$ \\
MS & - & $2.308,8$ & $2.155,8$ & $4.881,3$ & $211,42^{*}$ \\
GO & 90 & 1.026 & 2.478 & 6.114 & $6.793,33$ \\
DF & - & 90 & 83 & 140,5 & $56,11^{*}$ \\
Sul & $\mathbf{1 0 . 7 3 0}$ & $\mathbf{9 . 3 7 7 , 9}$ & $\mathbf{1 1 . 8 9 4 , 8}$ & $\mathbf{2 2 . 9 4 4 , 5}$ & $\mathbf{2 1 3 , 8 3}$ \\
PR & 4.600 & $3.853,9$ & $6.565,5$ & $11.915,6$ & 259,03 \\
SC & 480 & 468 & 559,7 & $1.104,3$ & 230,06 \\
RS & 5.650 & 5.056 & $4.769,6$ & $9.924,6$ & 175,65 \\
Nordeste & - & $\mathbf{1 5 6 , 3}$ & $\mathbf{1 . 3 0 0 , 1}$ & $\mathbf{3 . 8 6 7 , 2}$ & $\mathbf{2 . 2 4 7 , 2 1 ^ { * }}$ \\
MA & - & 8,8 & 252 & 1.084 & $12.318,18^{*}$ \\
PI & - & - & 35,8 & 496 & $1.385,47^{*}$ \\
PE & - & - & - & - & - \\
AL & - & 3,0 & 3,0 & - & - \\
SE & - & - & - & - & - \\
BA & - & 170 & $1.012,3$ & $2.297,2$ & $1.351,29^{*}$ \\
Sudeste & $\mathbf{8 7 5}$ & $\mathbf{1 . 7 2 4 , 4}$ & $\mathbf{2 . 4 9 8 , 4}$ & $\mathbf{4 . 0 0 5 , 4}$ & $\mathbf{4 5 7 , 7 6}$ \\
MG & 95 & 801 & $1.176,1$ & $2.567,9$ & $2.703,05$ \\
ES & - & - & - & - & - \\
RJ & - & - & - & - & - \\
SP & 780 & 923,4 & $1.322,3$ & $1.437,5$ & 184,29 \\
Norte & - & $\mathbf{1 , 1}$ & $\mathbf{2 8 , 6}$ & $\mathbf{1 . 0 7 9 . 9}$ & $\mathbf{9 8 . 1 7 2 , 7 2 *}$ \\
RR & - & 1,1 & - & 15,4 & $1.400^{*}$ \\
RO & - & - & 8,9 & 277,5 & $3.117,97^{* *}$ \\
AC & - & - & - & - & - \\
AM & - & - & - & - & - \\
AP & - & - & - & 140,5 & - \\
PA & - & - & 19,7 & 646,5 & $3.281,72^{* *}$ \\
TO & - & - & $\mathbf{2 6 . 1 6 0}$ & $\mathbf{5 8 . 3 9 1 , 8}$ & $\mathbf{4 8 0 , 7 8}$ \\
Brasil & $\mathbf{1 2 . 1 4 5}$ & $\mathbf{1 7 . 0 7 1 , 5}$ & &
\end{tabular}

* relativo aos anos de 1986/87 a 2006/07

** relativo aos anos de 1996/97 a 2006/07 FONTE: MAPA (2008)

Verifica-se pela tabela 1 e 2 que a cultura da soja, nos anos de 1980, transpõe as fronteiras dos estados do sul do Brasil e expande para o centro oeste: Mato Grosso ${ }^{6}$, Goiás e Mato Grosso do Sul (cerrados do Brasil Central ${ }^{7}$ ), nesse novo espaço ocupa uma região de clima tropical, graças à criação de novas cultivares adaptadas ao solo e clima do cerrado. O mapa 1 ratifica a análise anterior, em que se verifica que até a década de 1970 a produção se concentrou no sul do país, com algumas áreas em São Paulo e sul do Mato Grosso do Sul. Já na década de 1980, ela se amplia para o oeste de Minas Gerais e para o sudeste de Mato Grosso do Sul e chega a Goiás e até em Roraima. No ano 2003, é cultivada em quase todo o Brasil

\footnotetext{
${ }_{7}^{6}$ Maior produtor estadual de soja no Brasil na safra 2008/09

${ }^{7}$ Graças às variedades Doko e FT-Cristalina, genuinamente brasileiras.
} 
Central, sul de alguns estados do Nordeste e em muitas outras áreas do Norte do país como é possível averiguar no mapa abaixo.

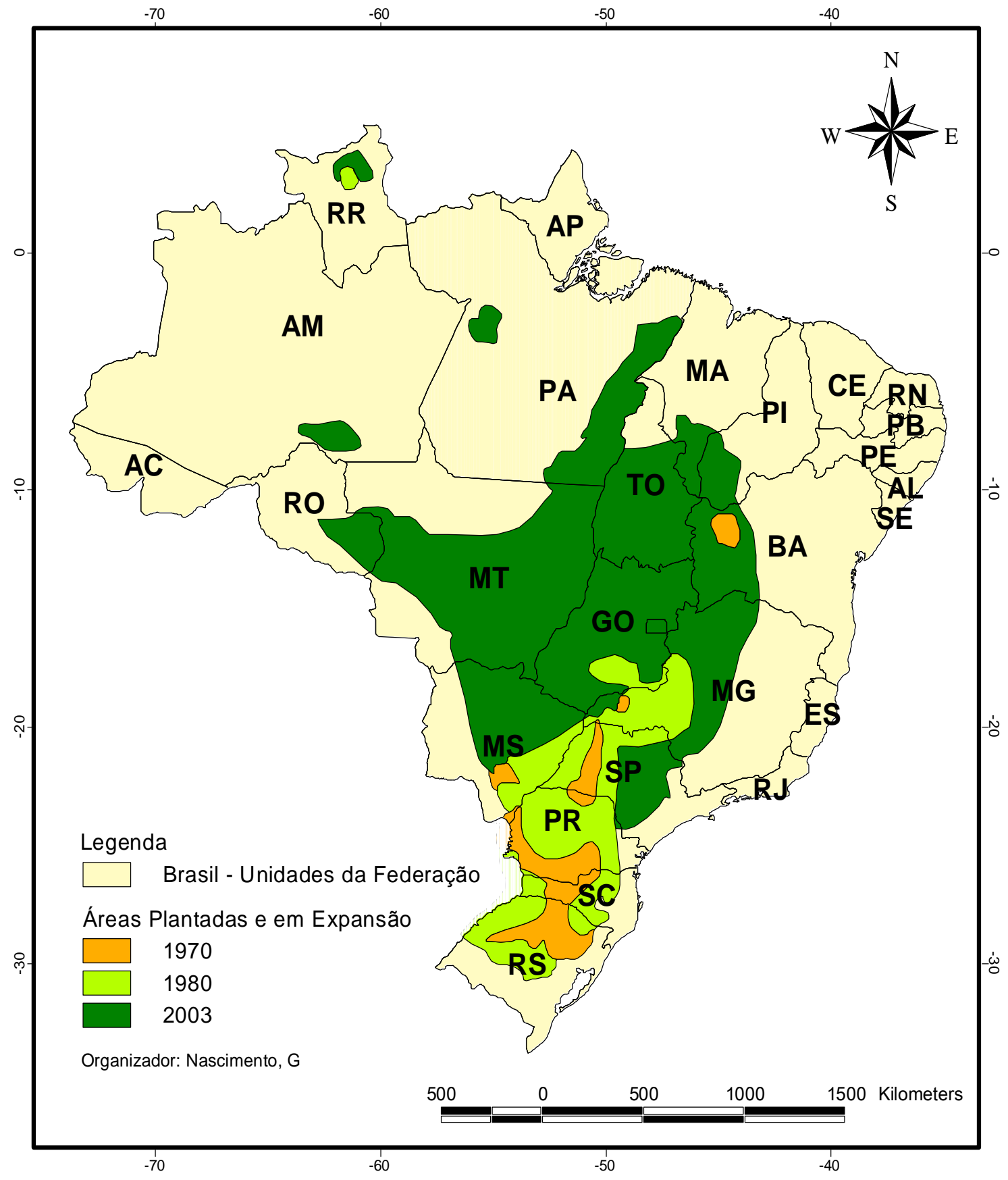

MAPA 1 - EXPANSÃO DA SOJA NO BRASIL

FONTE: BENNO BERNARDO KIRT ( 2003, p. 25) 
Muitos fatores contribuíram para que a soja se estabelecesse como uma das culturas de maior sucesso no território brasileiro, primeiramente na região sul (anos 1960 e 1970) e depois no Brasil Central (nas décadas de 1980 e 1990). Parte da incorporação dessas áreas se deve aos materiais genéticos produzidos em institutos de pesquisas brasileiros, voltados ao cultivo de soja em áreas tropicais, em especial o CNPSo, localizado em Londrina.

Segundo Dall' Agnol (2008, p.3), no contexto das grandes culturas produtoras de grãos, a soja foi a que mais cresceu em termos percentuais nos últimos 37 anos. De 1970 a 2007, o crescimento da produção global foi na ordem de $763 \%$, enquanto outras culturas como trigo, arroz, milho, feijão, cevada, girassol cresceram no máximo uma terça parte desse montante. Atualmente, o Brasil é o segundo maior produtor mundial (ver gráfico 1) de soja, com perspectivas para nos próximos anos ocupar o primeiro lugar em produção ${ }^{8}$.

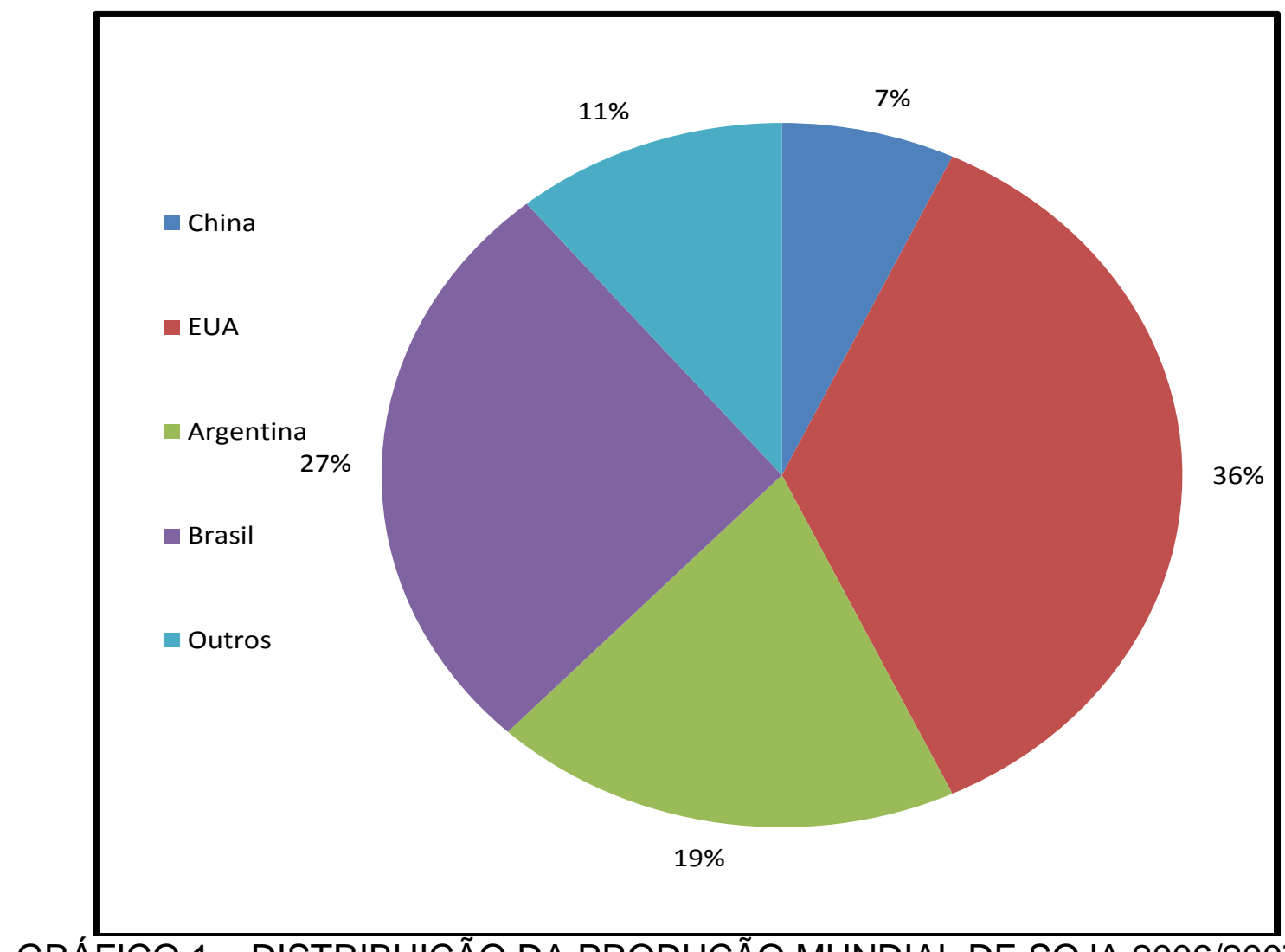

GRÁFICO 1 - DISTRIBUIÇÃO DA PRODUÇÃO MUNDIAL DE SOJA 2006/2007 FONTE: MAPA (2008)

\footnotetext{
${ }^{8}$ Segundo MAPA (2008a), o Brasil, na safra 2015/2016, será o maior produtor mundial de soja.
} 
O desenvolvimento de técnica, ciência e informação foi e está sendo determinante para a expansão da soja no território brasileiro, ao mesmo tempo em que cria cidades, novos objetos aparecem no espaço, outros mantêm a forma, mas muda a função, novas relações sociais são originadas, ações das empresas multinacionais e nacionais se materializam, na maioria das vezes expulsando o pequeno produtor e resignificando as funções dos fluxos e fixos dos lugares.

Segundo as projeções da USDA (2007), a demanda por soja continuará aumentando com o esperado crescimento do consumo nacional e mundial. Portanto, esse é um campo de investigação riquíssimo para o geógrafo que pretende analisar as metamorfoses do espaço habitado, em consequência da incorporação da soja em vários lugares do território nacional.

\section{MUDANÇAS TECNOLÓGICAS NA AGRICULTURA}

Ao mencionar o termo "modernização da agricultura" durante a redação desse artigo, baseou-se na definição de Graziano da Silva (1998, p.19), que considera que esse processo iniciou após Segunda Guerra, por meio das mudanças na base técnica da produção agropecuária.

As modificações na agricultura começaram já a partir do governo de Juscelino Kubitschek, quando ocorreu a consolidação do capital monopolista que teve impactos diretos na agricultura, na medida em que inicia uma série de transformações não somente na forma de produzir, mas em especial nas relações sociais de produção, com a introdução de novas formas de divisão social do trabalho.

Assim, a partir da implantação do capital monopolista, este passa a exigir da agricultura uma maior quantidade de matérias-primas para a indústria, alimentos a baixos preços para a população crescente e aumento da exportação de alguns produtos; a priori café e cacau, depois manufaturados e soja. Assim, o setor agrícola sofrera profundas modificações com a finalidade de atender a essa nova conjuntura.

Concomitantemente ao desenrolar da modernização, surgem os Complexos Agroindustriais que, para Sorj (1980, p.35): "pode-se dizer que o surgimento dos complexos industriais no Brasil se dá realmente com a implantação da indústria de 
maquinaria e insumos agrícolas, por volta do começo dos anos 1960, com início da produção de tratores"

A passagem dos Complexos Rurais para os Complexos Agroindustriais é um tema discutido por muitos autores (SORJ 1980, KAGEYAMA et al., 1989 e GRAZIANO DA SILVA 1998 e outros). Não há um consenso em relação ao momento dessa transição, já que Sorj fala do início da década de 1960, enquanto Graziano da Silva em 1950, a partir da implantação do Departamento 1 em bases industriais modernas.

Essa transição somente foi possível após a substituição da agricultura praticada de forma quase artesanal, para uma agricultura com atividades integradas à indústria, seja à "montante" ou à "jusante" do processo que provocou consequentes mudanças das relações de trabalho. Cabe salientar que outros fatores também foram preponderantes.

Somente a partir de 1930, com a Revolução, a racionalidade das políticas estatais se direcionou para a industrialização do Brasil. Logo, os Complexos Agroindustriais ${ }^{9}$ começaram a aparecer com tal, após esse período.

Quando se incorpora ao processo de produção agrícola os insumos (adubos e máquinas) há um rápido incremento de produtividade, e consequentemente, uma destruição da economia natural, ou seja, a técnica passa a controlar a natureza. Um solo impróprio para o plantio é corrigido, onde falta água, irriga-se, as pragas e doenças são combatidas com defensivos (GRAZIANO DA SILVA, 1998, p.3). Curvas em nível construídas para amenizar a erosão, herbicidas para acabar com as ervas daninhas entre outras técnicas de subordinação das condições naturais pelo capital. Portanto, a agricultura transforma-se em um ramo da indústria.

Assim, a agricultura não possui a mesma autonomia de antes, isto é, ela se industrializa e passa a depender da demanda dos setores urbanos para definir seus objetivos de produção. Mas, em que consistia essa autonomia?

Com a constituição do D1, com bases modernas e totalmente industrializadas, a agricultura pode se modernizar completamente. $\mathrm{E}$ isso, efetivamente, ocorreu a partir de meados da década de 1960, como pontua Sorj (1980). Cabe agregar nessa discussão a participação do Estado, num esforço de

\footnotetext{
${ }^{9}$ Tanto Sorj quanto Graziano da Silva são unânimes em dizer que o desenvolvimento do mercado interno, a partir do crescimento da produção agrícola, são fatores imprescindíveis para a transição.
} 
dinamizar a agricultura para atender o padrão de acumulação industrial nascente a partir de 1930, via desenvolvimento dos Complexos Agroindustriais. O suporte dado aos CAls foi o centro de atuação do governo e órgãos federais, visando integrar os estados fundamentalmente agrícolas à dinâmica da expansão capitalista. Para (SORJ, 1980), "a expansão da produção de soja permitiu um rápido processo de acumulação na indústria de insumos e máquinas e das empresas de comercialização" (SORJ, 1980, p.54)

Segundo Sorj (1980, p.28), o Estado, a partir de 1964, atrelou as forças sociais (o capital monopólico associado em porção secundária aos grandes proprietários de terra) vencedoras do conjunto da sociedade e forças externas ao campo para, juntamente, conduzir o processo de modernização (associar a agricultura ao novo circuito produtivo liderado pela indústria de insumos e processamento de matéria-prima e gerar as condições infraestruturais necessárias à expansão do conjunto do setor).

A consolidação da integração da agricultura com a indústria, ou seja, a formação dos CAIS ocorre a partir do advento do SNCR e das políticas de agroindustrialização, especificamente instituídas a partir dos chamados fundos de financiamentos, o que torna o grau das relações interindustriais mais complexas, diferente das relações de dominação do setor industrial sob a agricultura ao final do século XIX. Agora, a agroindústria passa a depender diretamente do desenvolvimento do setor industrial de máquinas e equipamentos para si própria e para a agricultura. O Estado também passou a representar interesses agrários, industriais e financeiros bem diversos daqueles do início do século XX. (GRAZIANO DA SILVA, 1998, p.31)

O Sistema Nacional de Crédito Rural constitui-se no elo do capital financeiro com a agricultura, destinado a sustentar e desencadear a modernização da agricultura:

Em resumo, a política de crédito rural subsidiado não apenas permitiu reunificar os interesses das classes dominantes em torno da estratégia de modernização conservadora da agropecuária brasileira, como também possibilitou ao Estado restabelecer o seu poder regulador macroeconômico mediante uma política monetário-financeira expansionista. Não é sem outra razão que a política de crédito rural é considerada o carro-chefe da política de modernização conservadora até o final dos anos 70 (GRAZIANO DA SILVA, 1998, p.51). 
Esse sistema ${ }^{10}$ tinha como propósito estimular o investimento e custeio rural, introduzir métodos racionais de produção, aumentar a produtividade, fortalecer economicamente os produtores rurais e ampliar a comercialização.

Para Sorj (1980), a política de crédito agrícola possui dois grandes objetivos: a modernização das forças produtivas da agricultura, fornecendo crédito ao complexo agroindustrial, um dos grandes receptores dos subsídios rurais ofertados pelo governo neste período; em outra instância, compensa a política de controle de preços, sendo uma transferência de renda, especialmente aos médios e grandes produtores, com maiores condições de reagir a essa política. Por outro lado, os pequenos produtores que ainda produzem de forma tradicional possuem poucas opções econômicas de modificar o tipo e o volume de produção.

Delgado (1985, p.111) destaca que as mudanças na base de produção rural e a constituição integrada do complexo agroindustrial tornam-se viáveis a partir do desenho de um sistema financeiro especificamente concebido para induzir e promover as mudanças técnicas e a associação dos grupos sociais reunidos no processo de modernização conservadora: grande capital, Estado e proprietários rurais.

Todos os países, que hoje figuram como os grandes produtores agrícolas mundiais, tiveram no Estado o agente promotor do desenvolvimento da agricultura moderna, por meio da criação de políticas públicas direcionadas ao amparo de uma agricultura mais tecnológica, possibilitando altos índices de produtividade e incorporação de novas áreas para o plantio. "Na agricultura, o processo de intervenção do Estado, em nível global, talvez tenha ocorrido de forma mais ampla e persistente do que em outros setores, porque ocorreu em larga escala, tanto nos países desenvolvidos como em países em desenvolvimento [...]" (COELHO, 2000, p.27)

No Brasil, esse processo foi iniciado nas primeiras décadas do século $\mathrm{XX}^{11}$, porém, foi efetivado a partir de 1960, principalmente após 1964 com o advento do governo militar, que atrelado ao capital internacional promoveu políticas de

\footnotetext{
${ }^{10}$ Sem esquecer que as políticas de tecnologia e a política fundiária, segundo Delgado (1985), constituía junto com SNCR no sustentáculo da dinamização da agricultura brasileira pós 1965.

${ }^{11}$ Foram centradas na criação de mecanismos de financiamento. A primeira foi a decisão de transformar o Banco do Brasil em fonte importante de apoio financeiro ao setor rural. E o lançamento de bases de um sistema de cooperativas, denominados caixa Raiffersen, que nunca teve participação importante na oferta de crédito.
} 
industrialização da agricultura, para atender as demandas internas e externas da mesma.

O governo militar foi sem dúvida o grande incentivador do processo de modernização da agricultura. Um dos objetivos era acelerar a substituição de culturas e a soja surge nesse momento como "carro chefe" desse processo.

Em relação às políticas econômicas realizadas no período de 1967 a 1973, e sua influência no setor agrícola, Lago (1990) pontua:

\begin{abstract}
A evolução favorável de diversos setores foi influenciada por políticas governamentais especificas. Assim, a agricultura beneficiou-se de farto volume de crédito concedido pelas autoridades monetárias, a taxas subsidiadas, e que foi uma das causas principais da expansão monetária no período. Destaca-se o surgimento da soja como produto e importância crescente na pauta de exportações e no consumo interno, enquanto o café perdia peso relativo dentro do setor agrícola e no total das exportações. (LAGO, 1990, p.239).
\end{abstract}

A partir de então, tanto as culturas voltadas para o mercado externo quanto para o interno são beneficiadas, embora a primeira recebesse mais incentivos.

No entendimento governamental, a agricultura para exportação deveria ser fomentada com o propósito de garantir divisas para que a substituição de importações continuasse, com um modelo fundado na dívida externa crescente e incentivos a expansão dos CAls.

Outro fator que dinamizou e ajudou a expandir e a modernizar a cultura foi a implantação de agroindústrias processadoras no Brasil $^{12}$, possibilitando exportar a torta de soja e o farelo, além de produzir o óleo para o consumo interno. Sorj (1981, p.33) destaca que de 1930 a 1960 surgem as primeiras grandes processadoras de alimentos para o mercado interno. Já, a partir de 1960, as multinacionais instalam-se no Brasil, provocando uma diversificação das indústrias agroalimentares para o mercado interno.

Sorj $(1980$, p.39) salienta a participação das multinacionais no processamento de rações para aves, bovinos e suínos no Sul (maiores produtoras de soja na década de 1970). Essas empresas foram responsáveis pela modernização do processo de produção da pecuária no Brasil (aves, gado bovino e

\footnotetext{
12 Sobre a implantação de agroindústrias nacionais cabe ver o trabalho de José Carlos Espindola (1999 e 2002 ver referências) que realizou um estudo da história de gênese e desenvolvimento do grupo Sadia no oeste catarinense.
} 
suíno) via modernização de granjas, orientação técnica aos produtores e plano de financiamento.

Sobre a participação das multinacionais da soja no Brasil, o secretário da agricultura dos Estados Unidos disse ao Jornal do Brasil em 1975:

\begin{abstract}
E mesmo que a produção continue a crescer aceleradamente nos próximos anos vencidos os problemas de infra-estrutura cada vez mais sérios- a ameaça à economia dos Estados Unidos fica minimizada pela participação ativa das multinacionais norte-americanas na industrialização, comercialização e fixação de preços nos lucros, enfim da soja brasileira (SORJ, 1980, p.83).
\end{abstract}

Atualmente, o panorama do controle do processamento de soja no país não se alterou muito. De acordo com DROS (2004, p. 9), o comércio e o processamento mundial de grãos de soja concentram-se nas mãos de um pequeno número de empresas multinacionais. Archer Daniels Midland, Bunge, Cargill (nos EUA) e Louis Dreyfuss, (França) controlam 43\% da capacidade de processamento no Brasil, quase $80 \%$ na União Europeia. As três empresas norte americanas controlam $75 \%$ do mercado de soja dos EUA.

\title{
4 A EXPANSÃO DA SOJA NO PARANÁ E TRANSFORMAÇÕES SOCIOESPACIAIS
}

O objetivo nesse item é correlacionar as políticas de modernização da agricultura com a expansão da soja. Para isso, escolheu-se o Paraná, estado de maior destaque na região sul no plantio de soja.

No sul do Paraná, de modo particular os campos gerais, a soja ocupou as áreas onde antes eram destinadas ao arroz sequeiro. O sudoeste e oeste com terras férteis, baixo preço e clima favorável foram alvo de disputa na década de 1960 por gaúchos e catarinenses, que foram os responsáveis pela introdução e expansão da soja nessa região e trouxeram consigo a experiência do seu cultivo. Realizando um consórcio com o trigo em 1972, a área cultivada de soja nessas regiões era superior a $40 \%$, já em meados da década de 1980 , representava $50 \%$ da produção total do Estado. Nessa mesma década, os gaúchos e catarinenses que introduziram a soja nessas regiões do Paraná migram para o sul do Mato Grosso, Goiás e iniciam o plantio de soja no centro-oeste. 
Contribuíram também para a expansão da soja no referido Estado a criação, em 1969, da Comissão Estadual de Sementes de Soja no Paraná, normalizando a produção de sementes, a criação do Instituto Agronômico do Paraná na estruturação de uma equipe de pesquisadores para essa cultura e também as cooperativas na execução de experimentação regional das sementes e do Instituto Privado de Óleo (INSTIÓLEOS), oferecendo suporte financeiro a essa atividade.

No norte do Paraná ${ }^{13}$, na década de 1950 e 1960 e ainda parte da década de 1970 suas funções e formas espaciais estavam direcionadas para a cultura do café. Milhares de pessoas ocuparam esse espaço geográfico com atividades relacionadas à cultura do café. Embora já no início de 1960 o governo interveio na cafeicultura $^{14}$, no sentido de racionalizar o cultivo e/ou substituí-lo por outras culturas, tendo em vista o projeto de modernização do setor rural em curso. (STOLCKE, 1986)

Cabe destacar ainda que a geada de 1953 forçou os produtores a plantar cereais como cultura, intercalando entre as "ruas" dos cafezais. Porém, esta ação não teve êxito devido às dificuldades de transporte e comercialização. Em 1955, procurando arranjar uma solução para outra grande geada ocorrida no mesmo ano, o Instituto Agronômico de Campinas sugeriu o cultivo da soja entre os cafezais para amenizar a situação. Nesse contexto, tais ações surgiram para incentivar outra cultura que pudesse ser colocada a bom preço no mercado internacional e que causasse o menor malefício aos cafezais em formação. A resposta do Paraná foi imediata: de 43 hectares plantados de soja em 1954, passou para 1.922 em 1955 e 5.253 em 1956.

$\mathrm{Na} z o n a$ rural, as relações de trabalho predominantes no início da década de 1960 era o colonato, "os colonos eram os mais numerosos entre os trabalhadores nas propriedades cafeeiras, o que nos indica a presença de médios e grandes

\footnotetext{
${ }^{13} \mathrm{Com}$ a incorporação dessa nova área, juntamente com o norte e a região central, ocorre um efetivo impulso na produção total da soja no Paraná, que passou de uma "média de 150 mil toneladas na década de 1960 para 3,5 milhões de toneladas na média dos anos de 1970, para 4,15 milhões de toneladas na década de 1980 e para 6,15 milhões de toneladas na média dos anos 1990" (D`AGNOLL, 2008. p.10).

${ }^{14}$ Segundo Fresca (2000, p. 162), o governo brasileiro, após a década de 1960, adotou o Programa de Erradicação do Café (GERCA) que ocorreu em três fases: a primeira, de 1962 a 1963, esta erradicou um elevado percentual de pés de café, a segunda, de 1964 a 1966, onde o processo de erradicação foi menor, devido as alterações políticas e econômicas ocorridas pós 1964 e, a terceira fase de agosto de 1966 até abril de 1967, essa teve exigência por parte do governo da obrigatoriedade de substituição do café por cultura agroalimentares, já que nas fases anteriores a substituição se deu pela expansão das pastagens.
} 
proprietários ligados à cafeicultura, atingindo $29 \%$ da população ativa na cafeicultura, seguido por parceiros $26 \%$ e das famílias dos proprietários $20 \%$. Os diaristas correspondiam a $10 \%$ e os empreiteiros $7 \%$, seguidos de outras categorias de menos importância" (CARVALHO, 1991, p. 42)

Com a chegada da soja, em especial no norte do Paraná (onde o binômio soja/trigo substituiu o café), com mais intensidade em meados da década de 1970, as relações de trabalho sofrem grandes transformações: a meação e parceria acabam e juntamente com os colonos assalariados estes foram obrigados a deixar as áreas rurais rumo as grandes cidades. A cultura da soja/trigo era cultivada via utilização de herbicidas, fertilizantes e máquinas agrícolas, que dispensam 0 trabalho humano "[...] a mecanização e, depois, a cientificização do mundo rural contribuem certamente, para a queda da participação da população rural na população total do Brasil” (SANTOS \& SILVEIRA, 2001, p. 211).

TABELA 3- EVOLUÇÃO DA UTILIZAÇÃO TECNOLÓGICA, MECÂNICA E QUÍMICA NO PARANÁ-1970 A 1995/96

\begin{tabular}{l|c|c|c|c|c|c}
\hline Elementos & 1970 & 1975 & 1980 & 1985 & $1995 / 96$ & $\begin{array}{l}\text { aumento } \% \text { entre } \\
\text { anos de } 1970- \\
1995 / 96\end{array}$ \\
\hline $\begin{array}{l}\text { Uso de adubo } \\
\text { químico }\end{array}$ & 56.424 & 122.597 & 207.011 & 229.143 & 221.754 & $293,01 \%$ \\
\hline $\begin{array}{l}\text { Uso de arado (tração } \\
\text { mecânica) }\end{array}$ & 18.883 & 59.785 & 90.526 & 97.570 & 99.032 & $424,45 \%$ \\
\hline $\begin{array}{l}\text { Uso de tratores } \\
\begin{array}{l}\text { Uso de máquinas } \\
\text { (plantio e colheita) }\end{array}\end{array}$ & 18.618 & 52.498 & 81.727 & 101.346 & 130.826 & $602,68 \%$ \\
\hline
\end{tabular}

FONTE: IBGE (2009a)

Obs: Nos Censos de 1970 e 1980, estes dados aparecem com o termo "colheitadeiras (automotrizes e combinadas)"

Os dados da tabela 3 demonstram a evolução da utilização tecnológica, mecânica e química nos estabelecimentos agrícolas paranaenses ao longo de 35 anos. Nela, pode-se observar que o Paraná adotou o pacote tecnológico da "Revolução Verde". Fleischfresser (1988, p.25) analisa alguns elementos que contribuíram para esse processo. "Essa situação determinou que os instrumentos de políticas: crédito agrícola, preços mínimos, taxas cambiais, assistência técnica oficial 
e outros, fossem utilizados para estimular a produção dos produtos de maior cotação comercial e induzir a aquisição dessas tecnologias"

TABELA 4: NÚMERO DE ESTABELECIMENTO E ÁREA TOTAL DOS ESTABELECIMENTOS AGROPECUÁRIOS POR GRUPOS DE ÁREA TOTAL EM MIL HECTARES-BRASIL

\begin{tabular}{l|l|l|l|l|l|l|l}
\hline & & até 100 & 100 a 500 & 500 a 1000 & $\begin{array}{l}1.000 \quad \text { a } \\
\text { mais } 10.000\end{array}$ & $\begin{array}{l}\text { Sem } \\
\text { declaração }\end{array}$ & Total \\
\hline 1970 & estab. & 4.454 .022 & 366.843 & 47.903 & 36.874 & 35 & 4.924 .019 \\
& área & 69.153 .199 & 75.658 .459 & 33.084 .216 & 116.249 .591 & - & 294.145 .466 \\
\hline 1975 & estab. & 4.500 .809 & 393.677 & 52.493 & 41.468 & 938 & 4.993 .252 \\
& área & 69.154 .283 & 79.689 .562 & 36.233 .482 & 138.818 .756 & - & 323.896 .082 \\
\hline 1980 & estab. & 4.614 .793 & 430.169 & 58.352 & 47.841 & 191 & 5.159 .851 \\
& área & 73.498 .602 & 86.629 .468 & 40.169 .719 & 164.556 .629 & - & 364.854 .421 \\
\hline 1985 & estab. & 5.225 .162 & 458.506 & 60.112 & 50.411 & 162 & 5.801 .809 \\
& área & 79.551 .798 & 90.601 .489 & 41.292 .068 & 163.940 .463 & - & 374.924 .929 \\
\hline $1995 / 96$ & estab. & 4.318 .861 & 411.557 & 58.407 & 49.358 & 68 & 4.859 .865 \\
& área & 70.575 .779 & 83.355 .220 & 40.186 .297 & 159.493 .949 & - & 353.611 .246 \\
\hline 2006 & estab. & 4.448 .648 & - & - & 46.911 & - & 5.175 .489 \\
& área & 70.691 .698 & - & - & 146.553 .218 & - & 329.941 .393 \\
\hline
\end{tabular}

FONTE: IBGE (2009a): Censos Agropecuários do Brasil: 1970, 1975, 1980, 1985 e $1995 / 96$ e 2006.

Obs:Não existe dados nos estratos de área de 100 a 500 e de 500 até 1.000 no ano 2006 por falta de detalhamento da fonte pesquisada.

Ao analisar os dados da tabela 4, percebe-se que do censo de 1970 a 1985 o número de estabelecimentos e a área aumentou em todos os estratos. Em decorrência da incorporação da fronteira agrícola em especial no centro-oeste. Porém, enquanto os pequenos estabelecimentos (até 100ha) tiveram um acréscimo de $17,31 \%$ (estabelecimentos) e $15,03 \%$ (área). Nos outros estratos, tanto 0 aumento do número de estabelecimentos quanto de área o acréscimo foi superior a $20 \%$. E, nos estratos de 1.000 a mais de 10.000 os estabelecimentos aumentaram em $36,71 \%$ e a área em $41,03 \%$. Fica evidente que os médios e grandes estabelecimentos aumentaram sua representatividade no espaço agrário brasileiro de 1970 a 1995/96 em comparação aos pequenos estabelecimentos. Já, de 1985 a 1995/96, houve uma redução em todos os estratos destacados na tabela acima, tanto em área como em número de estabelecimentos, porém os maiores percentuais foram em estabelecimentos de até 100ha, com 17,34\% no número e 11,28\% na área. O final da década de 1980 e início de 1990 marca um período difícil para a 
agricultura nacional com o desmantelamento de várias políticas de subsídios para a agricultura como o crédito rural, o programa de preços mínimos e Proálcool, fracasso de vários planos econômicos, período de hiper inflação (1989), forte recessão (1991), abertura da economia (1991), prejudicando alguns setores agrícolas que foram expostos à concorrência internacional e, por último, a sobrevalorização do real, que dificultou a exportação. Todos esses problemas tiveram consequências diretas no setor agrícola e os mais prejudicados foram os pequenos agricultores, embora os médios e grandes também sofreram com essas adversidades, como é possível verificar na tabela 4.

Uma comparação entre o censo agropecuário de 1995/96 para o de 2006 percebe-se um pequeno aumento tanto no número (3\%) quanto na área $(0,16 \%)$ ocupada pelos estabelecimentos de até 100 hectares. Enquanto os de mais de 1.000 sofreram também pequena redução na área e no número de estabelecimentos (4,95\%). Verifica-se a partir do ano 2000 a inclusão da agricultura familiar em programas governamentais e ainda uma efetiva recuperação da economia, além dos preços altos de commodities como a soja no mercado internacional. Estes fatos provocaram rápida expansão de culturas comerciais em especial a soja ${ }^{15}$, por todo território brasileiro, sendo cultivada tanto em pequenos, médios e grandes estabelecimentos.

Conclui-se que o processo de concentração fundiária que ocorreu em diversas áreas do Brasil intensificou-se a partir da década de 1990, foi concomitante a maior utilização de técnica, ciência e ampliação de capital aplicado na agricultura, possibilitando assim o desenvolvimento de culturas de caráter comercial, com expressivos ganhos de produtividade para atender a exportação, como a cana-deaçúcar e a soja, além do crescimento significativo do rebanho bovino ${ }^{16}$ que, geralmente, utiliza grandes estabelecimentos no modelo extensivo de criação. Ampliou-se após essa década a incorporação de grandes extensões de área em

\footnotetext{
${ }^{15}$ “No período 1995/2006, a soja apresentou um aumento de $88,8 \%$ na produção, alcançando 40,7 milhões de toneladas, em 15,6 milhões de hectares, com um aumento de $69,3 \%$ na área colhida. Em termos absolutos, representa um aumento de 6,4 milhões de hectares, caracterizando a soja como a cultura que mais se expandiu na última década. Grande parte desta área pertence à região CentroOeste" (IBGE, 2009b, s/p)

${ }^{16}$ Segundo o IBGE o crescimento do rebanho bovino no país foi de $12.1 \%$ de $1995 / 96$ a 2006 . Sendo a atividade principal dos estabelecimentos da agropecuária brasileira. O estado do Pará registra o maior aumento na ordem de $119.6 \%$.
} 
especial no centro-oeste, norte e nordeste ${ }^{17}$ para o plantio de soja, além da intensificação da agricultura comercial no sul e sudeste. Esses fatos foram uns dos responsáveis pelo aumento dos médios e grandes estabelecimentos no Brasil. Embora ainda existam muitos estabelecimentos inferiores a 100ha que produzem soja e outras culturas de exportação, em especial no Paraná e Rio Grande do Sul. Dados do censo agropecuário de 2006 demonstram que $16 \%$ da soja produzida no Brasil utiliza mão de obra familiar.

Ao analisar o total de estabelecimento dos últimos censos para o estado do Paraná é possível verificar na tabela 5 uma redução gradativa de 1970 a 1985 de $33.29 \%$, o contrário do que ocorreu no Brasil. Porém, a área ocupada por esses estabelecimentos nesse mesmo período aumentou em 14,17\%, uns dos motivos é o processo de modernização da agropecuária paranaense que, após a década de 1970, permitiu um processo de concentração fundiária e uma maior incorporação da área cultivada, por meio de culturas temporárias. De 1995/96 a 2000, houve um crescimento mínimo no número de estabelecimento em torno de 0,31\% $(1.176$ unidades), embora nesse mesmo período registrou-se uma diminuição da área em $8.45 \%$.

TABELA 5: NÚMERO DE ESTABELECIMENTO E ÁREA TOTAL DOS ESTABELECIMENTOS AGROPECUÁRIOS POR GRUPOS DE ÁREA TOTAL EM MIL HECTARES-PARANÁ

\begin{tabular}{|c|c|c|c|c|c|c|c|}
\hline & & até 100 & 100 a 500 & $\begin{array}{ll}500 & a \\
1000\end{array}$ & $\begin{array}{ll}1.000 \quad a \\
\text { mais } \\
10.000\end{array}$ & $\begin{array}{l}\text { Sem } \\
\text { declaração }\end{array}$ & Total \\
\hline 1970 & $\begin{array}{l}\text { estab. } \\
\text { área }\end{array}$ & $\begin{array}{l}536.208 \\
7.672 .390\end{array}$ & $\begin{array}{l}15.608 \\
3.131 .132\end{array}$ & $\begin{array}{l}1.550 \\
1.089 .617\end{array}$ & $\begin{array}{l}1.087 \\
2.732 .391\end{array}$ & $\begin{array}{l}35 \\
-\end{array}$ & $\begin{array}{l}554.488 \\
14.625 .530\end{array}$ \\
\hline
\end{tabular}

\footnotetext{
${ }^{17}$ Segundo dados do IBGE, o censo de 2006 demonstrou que "[...] relação às áreas de lavouras, observou-se aumento em todas as regiões, com ganho total de 9,7 milhões de hectares $(19,4 \%)$. No Norte, verificou-se mais 1,1 milhão de hectares, um aumento de $37,3 \%$, com destaque para 0 Amazonas (560 mil hectares ou 184,2\%). Na região Nordeste, o aumento foi de 725 mil hectares (5\%), com os maiores incrementos no Maranhão (609 mil hectares ou 33,1\%), Piauí (138 mil ou 11,4\%), Pernambuco (223 mil ou 15,2\%) e Bahia (347 mil hectares ou 7,2\%). No Sudeste houve aumento de 1,5 milhão de hectares (cerca de 13\%) nas áreas de lavoura, com destaque para Minas Gerais (aumento de 273 mil hectares ou 5,6\%) e São Paulo (1,3 milhão de hectares ou 25,4\%). Na região Sul, o aumento foi de 1,5 milhão de hectares (11,9\%), concentrados no Paraná (979 mil hectares ou 17,9\%) e Rio Grande do Sul (625 mil hectares ou 9,96\%). Em ambas as regiões, o aumento verificado nas áreas de lavouras foi decorrente da migração das áreas de pastagens. $O$ Centro-Oeste registrou o maior aumento de áreas destinadas a lavouras: 4,7 milhões de hectares $(63,9 \%)$, e todos os estados tiveram crescimentos importantes: Mato Grosso do Sul, 681 mil hectares $(45,4 \%)$; Mato Grosso, 2,87 milhões de hectares (83,5\%); Goiás, com 1,1 milhão de hectares (48,3\%); e Distrito Federal, com aumento de 26 mil hectares (37,1\%) " (IBGE, 2009b,s/p).
} 


\begin{tabular}{l|l|l|l|l|l|l|l}
\hline 1975 & estab. & 455.954 & 18.273 & 1.940 & 1.348 & 938 & 478.453 \\
& área & 7.134 .566 & 3.696 .366 & 1.361 .017 & 3.439 .012 & - & 15.630 .962 \\
\hline 1980 & estab. & 430.026 & 20.081 & 2.268 & 1.537 & 191 & 454.103 \\
& área & 6.976 .756 & 4.088 .271 & 1.578 .655 & 3.736 .645 & - & 16.330 .330 \\
\hline 1985 & estab. & 441.262 & 20.961 & 2.464 & 1.548 & 162 & 466.397 \\
& área & 6.973 .557 & 4.303 .120 & 1.714 .617 & 3.707 .567 & - & 16.698 .864 \\
\hline $1995 / 96$ & estab. & 342.925 & 22.821 & 2.611 & 1.450 & 68 & 369.875 \\
& área & 6.198 .026 & 4.744 .420 & 1.806 .245 & 3.197 .940 & - & 15.946 .632 \\
\hline \multirow{2}{2}{006} & estab. & 335.916 & - & - & 1.191 & - & 371.051 \\
& àrea & 5.517 .292 & - & - & 2.954 .951 & - & 15.286 .534 \\
\hline
\end{tabular}

FONTE: IBGE (2009a): Censos Agropecuários do Paraná: 1970, 1975, 1980, 1985 e 1995/96 e 2006

OBS: Não existe dados nos estratos de área de 100 a 500 e de 500 até 1.000 no ano 2006 por falta de detalhamento da fonte pesquisada.

Pode-se perceber, na tabela 5, que os estabelecimentos de menos de 100ha, a redução absoluta de 1970 para 2006 foi de 200.292 unidades, com um percentual $37.35 \%$, em relação a área ocupada por esses estabelecimentos a redução foi de $28,08 \%$. Enquanto nos estratos de 100 a 500 houve um aumento de $46.21 \%$ (7.213 estabelecimentos), entre os anos de 1970 a 1995/96, e a área aumentou em 51.12\%. O aumento maior ocorreu nos estratos de 500 a 1.000 (19701995/96), ou seja, nos grandes estabelecimentos, ficando em torno de $68.45 \%$ no número de estabelecimento e $65.39 \%$ em relação a área ocupada. Já, nos estratos de mais de 1.000 hectares, o aumento de estabelecimentos ficou em torno de $33.39 \%$ e a área aumentou $17.03 \%$. Conclui-se que estes expandiram por meio da incorporação de estabelecimentos com menos de 100 hectares, que perderam tanto em número de estabelecimentos como na área.

Consequentemente, esses dados evidenciam um aumento na concentração fundiária do Estado a partir da década de 1970, após a expansão de culturas que demandam maiores áreas e das facilidades na produção via incorporação de técnicas modernas de manejo, nas últimas safras, destaque para o plantio de transgênicos que dispensa mão de obra para os tratos culturais. Assim, o produtor pode ampliar sua área de cultivo.

Por conseguinte, a década de $1970^{18}$ demonstrou um dos mais intensos êxodos rural/urbano do Brasil, num rápido e intenso processo de esvaziamento demográfico do campo. Isto provocou alteração significativa nas paisagens rurais

\footnotetext{
${ }^{18}$ Segundo Santos e Silveira (2001, p. 210) [...] Entre 1985 e 1996, a população agrícola do Brasil perdeu uma massa de 5.464.029 trabalhadores e, desse modo, com um total de 17.930. 890 em 1996, retornava aos volumes de 1970 .
} 
com milhares de casas abandonadas circundadas por plantio de trigo ou soja. Durante a década de 1980 e início da década de 1990, parte da população expulsa voltou a trabalhar no campo como volante (o bóia-fria ${ }^{19}$ ) na cultura de algodão, canade-açúcar e café, em especial no norte e noroeste do Paraná. Em meados da década de 1990, o trabalhador volante continua a ser ocupado na cana-de-açúcar e café.

Em relação ao êxodo rural ocorrido no norte do Paraná, vários foram os fatores, destacando-se a introdução de máquinas agrícolas, o uso intensivo de insumos e a substituição de culturas, e expansão da pecuária, atrelado ao pacote tecnológico com um número reduzido de emprego de pessoas, dentre outros fatores.

TABELA 6- POPULAÇÃO URBANA E RURAL - BRASIL (1970 A 2000)

\begin{tabular}{l|l|l|l|l|l}
\hline Ano & Total & Urbana & $\%$ & Rural & $\%$ \\
\hline 1970 & 93.215 .301 & 52.108 .756 & 55.9 & 41.106 .545 & 44.1 \\
1980 & 119.070 .865 & 80.454 .712 & 67.6 & 38.616 .153 & 32.4 \\
1991 & 146.825 .475 & 110.990 .9990 & 75.6 & 35.834 .485 & 24.4 \\
2000 & 169.799 .170 & 137.953 .959 & 81.2 & 31.845 .211 & 18.8 \\
\hline
\end{tabular}

FONTE: IBGE (2009c)- Censos Demográficos (Brasil) 1970, 1980, 1991 e 2000.

TABELA 7- POPULAÇÃO URBANA E RURAL - PARANÁ (1950-2000)

\begin{tabular}{l|l|l|l|l|l}
\hline & 1970 & 1980 & 1990 & 1996 & 2000 \\
\hline Urbana & 2.504 .378 & 4.472 .561 & 6.197 .953 & 7.011 .990 & 7.786 .084 \\
Rural & 4.425 .490 & 3.156 .831 & 2.250 .760 & 1.991 .814 & 1.777 .374 \\
Total & 6.929 .868 & 7.629 .392 & 8.448 .713 & 9.003 .804 & 9.563 .458 \\
\hline
\end{tabular}

FONTE: IPARDES (2009)

$\mathrm{Na}$ análise dos dados da tabela 6 , que se referem ao total da população rural e urbana brasileira, observa-se um decréscimo da população rural nos últimos anos. Em 1970, contava com 44,1\% do total; em 1980, representava 32,4\%; e, em 1991, $24,53 \%$ e no último censo apenas $18,8 \%$. Enquanto a população urbana registrou altos índices de crescimento, em 1970, 55,9\% e, em 2000, 81,2\% do total populacional brasileiro residia na zona considerada urbana. Essa tendência de

\footnotetext{
${ }^{19}$ Broietti (2003) realizou um estudo da inserção do trabalhador volante no processo de transformação do espaço agrário de Florestopólis (município localizado no norte do Paraná). Por meio desse trabalho é possível vislumbrar a dinâmica desse trabalhador na referida região e quais os atores hegemônicos interessam esse tipo de trabalho.
} 
redução da população rural também foi registrada no Paraná conforme a tabela 7 . Mesmo havendo um crescimento de $38 \%$ na população total, a população rural diminui em números absolutos de 2.648.116 habitantes, um percentual de 59,83\% e a urbana aumentou $210,89 \%$ nos últimos 30 anos. Cabe ressaltar que grande parte do contingente de população rural do Paraná ${ }^{20}$ migrou para a fronteira agrícola do centro-oeste, em especial na década de 1980; se beneficiando dos subsídios ofertados pelo governo, via programas de incorporação produtiva dessas áreas: POLOCENTRO, PRODECER e outros. Mas, o aumento da população urbana do Paraná também demonstra que grande parte dessas pessoas migraram do campo para a cidade paranaense.

Sobre o êxodo rural no Paraná e os fatores determinantes Fleischfresser (1988) coloca que:

[...] Esse movimento que eclodiu na década de 70, já se encontrava em estado latente a partir de segundo quinquênio dos anos 60 , devido a erradicação dos cafezais. Só que neste período, a população excedente dos cafezais localizados no Norte do Paraná se deslocava em direção as " fronteiras agrícolas" no Estado. Entretanto, nos anos de 70, quando gradativamente se esgota, concomitante ao processo e intensificação no uso da modernização tecnológica (caracteristicamente poupadora de mãode-obra) e a substituição de culturas, agora não mais somente o café, mas também alimentares, por soja e pecuária, verifica-se uma notável evasão da população residente no meio rural. (FLEISCHFRESSER, 1988, p.21).

A notável evasão da população rural nas $\mathrm{MRH}$ do norte se efetiva quando há conjugação de vários fatores tais como: a erradicação do café através dos programas oficiais, a ocorrência de fortes geadas (principalmente de 1969 a 1979) a substituição de culturas (café e alimentares por soja, produzida sob base técnicas e novas relações de produção): a incorporação de inovações técnicas ao processo de produção do próprio café, a expansão da pecuária e a concentração da terra. (FLEISCHFRESSER, 1988, p.69).

A efetiva redução da população rural e os problemas decorrentes desse processo levaram Graziano da Silva (1982) a denominá-la de "modernização dolorosa", pois, com a intensificação das relações capitalistas na agricultura, o pequeno descapitalizado foi excluído do processo, privilegiando o capital monopolista, principalmente os Complexos Agroindustriais que canalizam quase

\footnotetext{
${ }^{20}$ Santos e Silveira (2001, p. 214) destaca que [...] no início da década de 1980 , o valor das terras no norte do Paraná dobra e leva os pequenos e médios produtores a vender suas glebas e a procurar uma nova atividade em outras áreas agrícolas ou na cidade.
} 
todos os subsídios ofertados pelo Estado para se desenvolver e monopolizar o espaço agrário.

Vale ressaltar que o espaço rural paranaense tornou-se o "locus" da modernidade pós-cientificização da agricultura, em parte graças ao complexo sojicultor, modificando assim os arranjos e configurações das paisagens rurais e urbanas, e com consequente geração de uma série de metamorfoses no espaço habitado. Todas essas transformações afetaram de modo radical a estrutura fundiária, provocando um processo de concentração. No entanto, a pequena produção permaneceu no centro-sul, conforme demonstram várias pesquisas.

Por outro lado o governo procurou incentivar a inserção do produtor rural no sistema integrado de cooperativas, que se constituem num mecanismo de garantia da permanência do pequeno e médio produtor na zona rural. Em especial, no sul do Brasil. Entre as dez maiores cooperativas do Brasil, em relação à receita, sete são paranaenses $^{21}$, indicando a influência desses grupos no plantio, processamento, armazenagem e comercialização da soja e de outras culturas agroalimentares nesse estado. A participação das cooperativas no setor agroalimentar se aprofundou após a década de 1990, quando o Estado brasileiro diminuiu os recursos destinados ao crédito rural e decretou o fim da política de preços mínimos. Assim, o produtor precisou recorrer às cooperativas ou as tradings para conseguir empréstimos e custear a produção, através da venda antecipada de sua produção a esses grupos. (MEDEIROS, 2009)

Vários órgãos do próprio Estado, que antes "endossou" o êxodo rural, atualmente trabalham para atenuar esse processo e, muitas vezes, realizar 0 movimento contrário.

[...] Objetivando atenuar essa situação, as cooperativas agropecuárias regionais, a SEAB- por meio dos seus órgãos e empresas, as Prefeituras Municipais e entidades classistas vêm desenvolvendo, em conjunto, um trabalho de orientação, junto aos pequenos e médios produtores, para diversificação da produção (sericicultura, fruticultura de mesa, pecuária leiteira, cultura do café, da mandioca e do milho entre outras). Esperançosos de que a produção diversificada, ao possibilitar a reprodução mais rápida e contínua do capital, contribuirá para reter o homem no campo desacelerando o êxodo rural (MORO, 1991, p. 340).

\footnotetext{
${ }^{21}$ Por ordem de tamanho, Medeiros (2009, p. 102) destaca Coamo (PR), Itambé (MG), C. Vale (PR), Cocamar (PR) Coopercitrus (SP), Cooperativa Integrada (PR) Cooperalfa (SC), Copacol (PR) e Entre Rios (PR)
} 
Mais recentemente, o governo criou outras políticas que têm como objetivo precípuo fixar o homem na zona rural e diminuir as pressões habitacionais na cidade e os problemas gerados a partir dela: Vila Rural ${ }^{22}$ e assentamentos.

\section{CONCLUSÃO}

Tudo indica que a soja é uma cultura que interessava tanto o governo, como latifundiários e a burguesia industrial ${ }^{23}$, caso contrário, não teria uma expansão tão significativa nas últimas décadas no território nacional, pois o setor de soja teve status especial e mereceu grande atenção por parte dos formuladores de política econômica.

Entre as diversas formas de transferência de recursos financeiros para o setor, é importante destacar o crédito agrícola, políticas de garantia de preço mínimo, programa de subsídio do trigo, as políticas de erradicação do café, incentivo da pesquisa agrícola, em especial a criação da EMBRAPA/Soja, os programas de ocupação do cerrado, preço uniforme do frete, entre outras. Na maioria das vezes, a soja foi a cultura mais beneficiada e todos esses elementos foram uma alavanca para a incorporação de muitas regiões pela soja e, consequentemente, o palco de transformações socioespaciais.

Portanto, a configuração espacial do espaço rural e urbano, do Estado do Paraná, recebeu novos objetos geográficos (agroindústrias, cooperativas, bancos direcionados ao crédito rural, empresas de pesquisa agrícola, casas de comércio de insumos, escritórios para atender as mais variadas demandas da agricultura científica, maquinários, efetiva modernização e ampliação da rede de transportes, estradas, portos e de comunicações) e novos arranjos (favelas, vilas abandonada no campo, fim das festas rurais, migrações pendulares dos trabalhadores volantes, perda da solidariedade e coletividade entre as populações rurais e outros). Contudo,

\footnotetext{
${ }^{22}$ Criado em 1995, o programa de Vilas Rurais repassa à família um lote de 5 mil metros quadrados, uma moradia com 45 metros quadrados, um galinheiro e um depósito de produtos e instrumentos de trabalho; e também recebe treinamentos e insumos para fazer a transição para um novo tipo de vida. Durante 30 meses, a família selecionada recebe todo o apoio necessário para trabalhar a terra e, no final desse período, assina um contrato de financiamento de 25 anos, no valor médio de $R \$ 40$ mensais.

${ }^{23}$ Cabe lembrar que essas duas classes formaram em 1930 uma coalizão para comandar a política e a economia brasileira, e tinha como pressuposto fomentar o processo de industrialização e dinamização da agricultura, tanto a que atendia o mercado interno como o externo
} 
é pertinente afirmar que, após o aumento do plantio da soja nessa região, as relações existentes entre campo e cidade tornam-se mais complexas, como apontam Santos e Silveira (2001), requerendo uma análise criteriosa por parte do pesquisador, com a finalidade de apontar as novas espacialidades.

\section{REFERÊNCIAS}

BENNO BERNARDO KIRT, Anuário brasileiro da soja 2003. Santa Cruz do Sul: Editora Gazeta Santa Cruz, 2003.

BERNADES, J. A As estratégias do capital no complexo da soja. In: CASTRO, I. E., GOMES, P. C. C., CORRÊA, R. L. (org.). Brasil: questões atuais da reorganização do território. Rio de Janeiro: Bertrand Brasil, 1996.

BERTRAND, J. LAURENT, C. LECLERCQ, V. O mundo da soja. São Paulo: Hucitec, 1987.

BROIETTI, M. H. Os assalariados rurais temporários da cana. São Caetano: CUT, 2003.

BONATO, E, R. A soja no Brasil: história e estatística. Londrina: EMBRAPACNPSo, 1987.

CARVALHO, M. S. A produção de café no Paraná. 1991. Tese (Doutorado em Geografia)-Faculdade de Filosofia, Letras e Ciências Humanas, Universidade de São Paulo, São Paulo, 1991.

COELHO, C. N. Agribusiness" brasileiro e as macrotendências mundiais. Revista de Política Agrícola. São Paulo, ano 9, n.01, p. 27-37, jan.fev.mar. 2000.

DELGADO, G. C. Capital financeiro e agricultura no Brasil. Campinas, SP: UNICAMP, 1985

DALL' AGNOL A. Soja: o fenômeno brasileiro. Londrina: EMBRAPA, 2008.

DROS, J. M. Administrando os avanços da soja: dois cenários da expansão do cultivo da soja na América do Sul. Amsterdã: Aindenvironment, 2004.

ESPINDOLA, C. J. As Agroindústrias do Brasil: o caso Sadia. Chapecó: Grifos, 1999.

As Agroindústrias de carne do Sul do Brasil. 2002. Tese (Doutorado em Geografia)-Faculdade de Filosofia, Letras e Ciências Humanas, Universidade de São Paulo, São Paulo, 2002.

FLEISCHFRESSER,V. Modernização tecnológica da agricultura. Curitiba: Livraria Chain, 1988. 
FRESCA, T. M. Transformações da Rede Urbana do Norte do Paraná: Estudo Comparativo de Três Centros. 2000. Tese (Doutorado em Geografia)-Faculdade de Filosofia, Letras e Ciências Humanas, Universidade de São Paulo, São Paulo, 2000.

GRAZIANO da SILVA, José. A nova dinâmica da agricultura brasileira. Campinas, SP: UNICAMP/IE, 1998.

A modernização dolorosa: estrutura agrária, fronteira agrícola e trabalhadores rurais no Brasil. Rio de Janeiro: Zahar Editores, 1982.

IBGE. Censos Agropecuários-Brasil e Paraná: 1970, 1975, 1980, 1985, 1995/96 e 2006 Disponível em: <http;//www.ibge.gov.br.htm>. Acesso em: 25/11/2009a.

Censo Agro 2006: IBGE revela retrato do Brasil agrário. Disponível em: http://www.ibge.gov.br/home/presidencia/noticias/noticia_visualiza.php?id_noticia=14 64\&id_pagina=1. Acesso em 22/11/2009b

.Censos Demográficos- Brasil: 1970, 1970, 1980, 1991, 2000. Disponível em; <http;//www.ibge.gov.br.htm>. Acesso em: 25/11/2009c.

IPARDES. Anuário Estatístico do Estado do Paraná. Disponível em: http://www.ipardes.gov.br/anuario_2008/index.html. Acesso em 20/09/2009.

KAGEYAMA, A. et al. O novo padrão agrícola brasileiro: do complexo rural aos complexos agro-industriais. Campinas: UNICAMP, 1989.

LAGO. L. A. C. A retomada do crescimento e as distorções do "Milagre". IN: ABREU, M. P. (org.). A ordem do progresso: cem anos de política econômica republicana 1889-1989. Rio de Janeiro: Editora Campus, p. 233-294, 1990.

LESSA,. C. Quinze anos de política econômica. São Paulo: Brasiliense, 1982.

MAPA.Soja: Série histórica: Disponível em: http://www.agricultura.gov.br/ Acesso em: $25 / 08 / 2008 b$

MEDEIROS, M. A geografia econômica do setor agroalimentar brasileiro: investimentos, recursos ociosos e dinâmica cíclica (1990-2007). 2009. Tese (Doutorado em Geografia)- Faculdade de Filosofia, Letras e Ciências Humanas, Universidade de São Paulo-USP, São Paulo, 2009.

MIYASAKA, S. MEDINA, J. C. A soja no Brasil. Campinas: ITAL, 1981

MORO, D. A Substituição de culturas, modernização agrícola e organização do espaço rural, no Norte do Paraná. 1991. Tese (Doutorado em Geografia)Universidade Estadual Paulista, Rio Claro, 1991.

SANTOS, M. \& SILVEIRA, M. L. O Brasil: território e sociedade no inicio do século XXI. São Paulo: Editora Record, 2001. 
SORJ, B. Estado e Classes Sociais na Agricultura Brasileira. Rio de Janeiro: Zahar, 1980.

STOLCKE, V. Cafeicultura: homens, mulheres e capital (1985-1980). São Paulo: Editora Brasiliense, 1986.

USDA- United States Department of Agriculture. World Agricultural Supply and Demand Estimates. Disponível em http://usda.mannlib.cornell.edu/MannUsda/viewDocumentInfo.do?documentID=1194, Acesso em: 18/12/2007

(Recebido em 04.04.2010. Aceito em 22.04.2011) 